\title{
MODEL INSTITUTIONAL INFRASTRUCTURES FOR RECYCLING OF PHOTOVOLTAIC MODULES
}

\author{
Sheldon J. Reaven, Paul D. Moskowitz and Vasilis Fthenakis
}

January 1996

BIOMEDICAL AND ENVIRONMENTAL ASSESSMENT GROUP ANALYTICAL SCIENCES DIVISION DEPARTMENT OF APPLIED SCIENCE BROOKHAVEN NATIONAL LABORATORY ASSOCIATED UNIVERSITIES, INC.

Under Contract No. DE-AC02-76CH00016 with the U. S. Department of Energy 


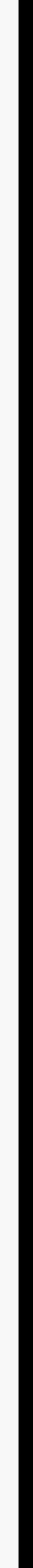




\section{TABLE OF CONTENTS}

Page

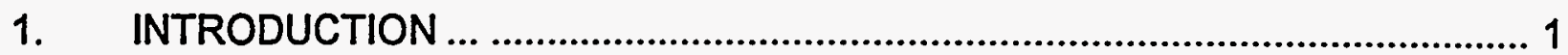

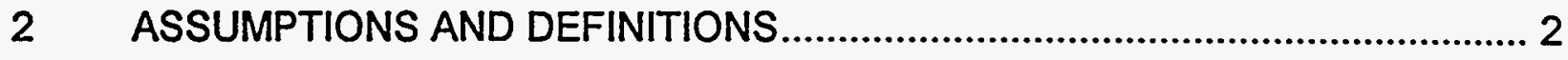

3. THE ELECTRONICS MODEL

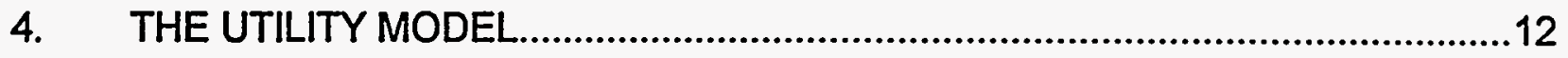

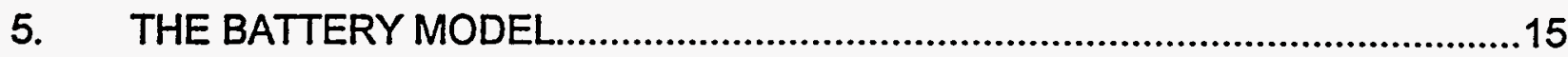

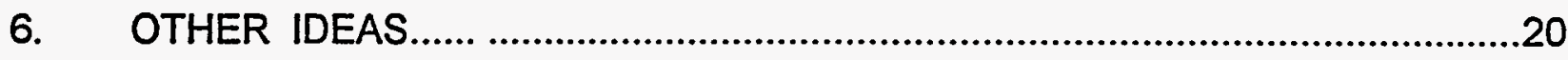

6.1 Retail-Based Collection at Home Depots.............................................22

6.2 PVM Collection by Commercial Glass Trucks.......................................22

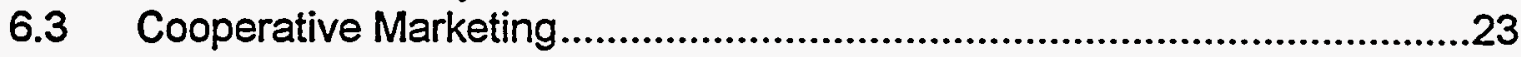

6.4 Recycling Hotline for Do-It-Yourself...................................................23

6.5 Designing Stackable, Standardized PVMs for Cheaper Shipping ...........24

6.6 Public Relations Initiatives to Focus Interest in PVM Recycling ...............24

6.7 Modifying MRFs to Accommodate PVMs ...........................................24

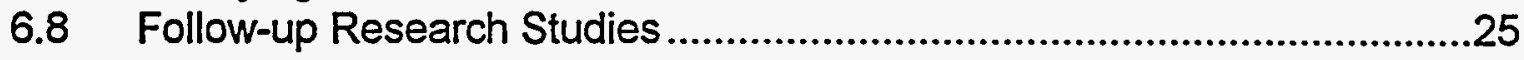

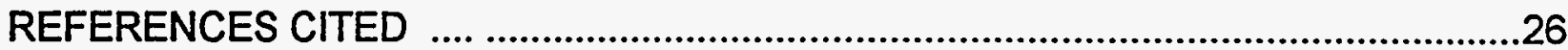





\section{INTRODUCTION}

How will photovoltaic modules (PVMs) be recycled at the end of their service lives? This question has technological and institutional components (Reaven, 1994a). The technological aspect concerns the physical means of recycling: what advantages and disadvantages of the several existing and emerging mechanical, thermal, and chemical recycling processes and facilities merit consideration? The institutional dimension refers to the arrangements for recycling: what are the operational and financial roles of the parties with an interest in PVM recycling? These parties include PVM manufacturers, trade organizations; distributors, and retailers; residential, commercial, and utility PVM users; waste collectors, transporters, reclaimers, and recyclers; and governments.

The PVM recycling system will have to be designed with great care because of decades-long intervals between installing and discarding PVMs, their low discard rates at likely market penetrations, marginal economics for recovery of low-concentration metals, and other factors (Reaven, 1994a). There are no ready-made solutions to these problems.

The present study will identify promising approaches to designing an institutional infrastructure to ensure the recycling of PVMs, in light of experiences in other industries, with other products and materials. (1) There is a predominantly private, fully articulated institutional infrastructure in the aluminum, scrap iron, and container glass industries, where recycling is a longstanding, even venerable, practice. Nevertheless, even in these industries, arrangements are constantly evolving in response to regulatory changes, competition, and new technological and market niches. (2) Institutional infrastructures are less settled for younger ${ }^{1}$ large-scale recycling industries that target components of the municipal solid waste (MSW) stream, such as cardboard and newspaper, polyethylene terephthalate (PET) and high-density polyethylene (HDPE) plastics, and textiles, for which economics, markets, and technologies are fluid [e.g., Breslin, Reaven, and Schubel, et al., 1993]. Generally, these infrastructures depend equally on private and public operations and finances. (3) Finally, many other industries have begun to mount projects to ensure that their products are recycled (and recyclable) e.g., computers, non-automotive batteries, communications equipment, motor and lubrication oil and oil filters, fluorescent lighting fixtures, automotive plastics and shredder residues, and bulk industrial chemical wastes. For products or materials in categories (2) and (3), the lack of an adequate recycling infrastructure, attractive end markets, and clear economic incentives, can be formidable impediments to a selfsustaining recycling system.

1. Recycling per se is nothing new for many of these materials. Recycling of rags and textilecontent paper was widespread in the 19th and early 20 th centuries. The Second World War saw many recycling drives; recycled content has long been used in certain paper products, such as boxboard. However, these earlier efforts do not compare in magnitude and scope with their current ones, and the recycling technologies themselves have advanced dramatically. 
We reviewed developments in the above industries, 2 and from that distilled three broad paradigms that could be followed in arranging the institutional infrastructure for PVM recycling. Also, several specific measures were found that make PVM recycling more effective and economical.

\section{ASSUMPTIONS AND DEFINITIONS}

End-of-life PVM discards are assumed to arise from three kinds of generators; homes, commercial and industrial sites, and utility arrays. ${ }^{3}$ We assume for this study that the PVM industry has identified the recycling technologies ${ }^{4}$ for the PVM discards and has designated the recovery facilities to which the discards are to be brought. Recovery facilities are assumed to be of two sorts: dismantlement facilities, where products are broken down, sorted, reused or reclaimed where possible, and segregated into materials streams, such as plastics, metals, and glasses, and the actual recycling facilities, where the materials streams are mechanically, chemically, or thermally processed. 5

2. The complete review is not reported here, since, for several products, materials, or industries, the infrastructure arrangements was inappropriate for PVM recycling.

3. For this report, homes include small multi-family units, such as duplexes, as well as single-family houses; commercial and industrial sites include apartment buildings; and utility arrays include large fields and smaller groupings, e.g., at commuter station parking lots. These discard streams may be supplemented by materials from PVM manufacturing and assembly plants, such as PVM and PVM component rejects and trim scrap; however, bulk chemical and manufacturing process wastes are not included.

4. The preferred recycling technologies can depend on the kind of module. The more promising technical avenues for recycling CdTe and CulnSe 2 PVM modules are surveyed in Reaven (1994a). These include (a) integration with electronics recycling or comprehensive metals recycling complexes; (b) co-processing with certain other multi-material waste streams; (c) incorporation into bulk secondary materials; and (d) emerging technologies for metal recovery, pyrolysis, solvent dissolution, and molten metal baths. Sasala, Zhou, and Kocher (1994) described new chemical approaches for Cd recovery.

While it is a matter of speculation, more advanced technologies, such as microbes that decompose plastic substrates and components (which can be designed with this fate in mind), membrane-separation metal recovery, biological recovery of heavy metals from solution, advanced granulators for plastic/metal films, and high-speed automated sorting, could lead to better, cheaper options for PVM recycling [IGT 1994; Busche 1994; Parry 1995; Ehrig, 1994; Unsigned 1994].

5. The recycled materials that result from mechanical processes, in turn, may be made or incorporated into a recycled product at another facility. Some designated recovery facilities may combine dismantlement and recycling operations. The materials streams are likely to be highly specialized in terms of resin, metals content, grind size, contamination and quality control. As noted in Reaven (1994a), some applications have greater tolerance for compositional variation within a particular materials stream, or for composite admixtures. 
For each type of recovery facility, dismantling and recycling, two broad options are available; dedicated, in which the facility exclusively handles PVMs, and perhaps, closely related products, and integrated, where the PVMs are one of several kinds of products or materials accepted by the facility. The question of ownership and financing is independent of this distinction. A dedicated or integrated facility can be owned, managed, or financed by a single PVM manufacturer, a PVM trade consortium, a manufacturer in another industry, an independent recycling company, or some other party.

The crux of the problem of the recycling institutional infrastructure problem now may be defined: what are the best design options for systems that deliver the PVM discards from the locations where they are generated to the recovery facilities? What institutional players are responsible for doing what? Answers to these questions have to considered logistical, contractual, and economic arrangements.

We present three broad infrastructure paradigms that best fit the circumstances of the PVM industry in this preliminary study, along with several suggestions for developing a viable recycling infrastructure that cuts across the three paradigms; our findings are based upon a review of institutional arrangements for recycling that are in place or under development for other materials, products, or industries. We recommend that the three paradigms and other suggestions next undergo a detailed economic and logistical analysis for various scenarios, and that the PVM industry begin discussions with several of the companies designated in this report to try to expand promising arrangements for institutional infrastructures. Then, it should be possible to prepare a definitive plan for the institutional infrastructure (also depending on which recycling technology is selected). Because fiscal information is often proprietary and confidential, the "best case" parameters may not be available for us to quantify or use for economic prediction.

For convenience, the three model infrastructures may be referred to as the utility model, the electronics model, and the (NiCd) battery model. In the first, utility endusers take primary responsibility for seeing that discarded PVMs are collected, brought to recovery facilities, and recycled. In the battery model, the manufacturers collectively bear this primary responsibility, by creating industry-wide entities narrowly chartered to

Provisions for refurbishing and reusing products in the United States or elsewhere also may be part of the recovery plan. The designated recovery facilities generally do not include intermediate facilities, such as transfer stations or storage locations, although such facilities typically would be employed. The idea is to leave matters about any intermediate facilities within the province of the institutional infrastructure. However, even for the actual recycling facilities, matters of finance, and contractual arrangements do fall within the province of "institutional infrastructure." For instance, a highvalue item will be sought by the ultimate recycler, who may be willing to pay to obtain the discards, and help finance their collection or provide logistical assistance. Recyclers overcome their traditional reluctance to become involved in collecting, sorting, and upgrading when the economic reward is sufficiently attractive. 
recycle a specific product (perhaps driven by specific regulatory mandates). In the electronics model, individual manufacturers shoulder this primary responsibility, within a fluid web of reverse logistics services, recyclers, and other manufacturers, and as part of a system that handles a range of products in integrated facilities.

These characterizations are rough. Infrastructure systems do not always fit these categories perfectly because of the numerous variations and permutations of their design. For example, the infrastructure for collecting and dismantling the material can be dedicated, while the actual recycling is integrated; an industry-wide entity can pay and let contracts for transporting the PVMs from a transfer station to recycler, while a municipality physically handles primary collection with partial subsidy from industry.

The three models roughly correspond to different conceptions of the role of PVMs. In the utility model, PVMs are regarded as a component of the system for generating and delivering electricity - just like a furnace, power line, pole transformer, current meter, or power plant - irrespective of whether the utility actually owns them. In the electronics model, PVMs are treated as yet another durable consumer electronic product, like a computer, VCR, or cadcam, incorporating high-technology circuitry and advanced materials. In the battery model, the PVMs may be likened to very big household batteries that are "recharged" by sunlight, and similarly may require special regulatory handling.

The next three sections of this paper explain the models in light of developments in corresponding industries. Then, additional suggestions are given that should not be associated with a single paradigm of PVM recycling infrastructure.

No assumption is made as to whether the recovery system generates enough revenue to pay for itself, or whether it is a net cost that ultimately is reflected in the price of goods. This is not an economic study, we do not attempt to estimate the costs associated with the recycling system. The record in other industries cannot be used to gauge the economics of PVM recycling; for example, the latter will not mirror those for NiCd batteries. ${ }^{6}$

A companion study (Reaven, 1994a) considers some institutional aspects of PVM recycling that are not covered in the present report.

\section{THE ELECTRONICS MODEL}

In this model (a) manufacturers first set up product take-back programs that generally rely on (b) reverse logistics companies for transportation, and (c) independent private (or in-house) private dismantling, sorting, and size-reduction

6. See the arguments on the logistics and economics of collecting PVM discards versus nicads in Reaven (1994a). 
facilities that themselves (d) recycle, or take responsibility for arranging the recycling of, the resulting materials streams. The transportation, dismantling, and often, the physical recycling operations are accomplished in integrated, specialized, facilities. The idea behind the model is to depend on full-service, one-stop facilities at stages (b) and (c). Seeing an opportunity, some entrepreneurs are creating new hybrid services that combine stages (b), (c), and (d), and otherwise rearrange the oftenoverlapping functions within recycling infrastructures. On-call reverse logistics companies are ideal for arranging pick-ups of used residential and commercial PVMs.

Much of the impetus for this approach comes from existing and impending European "manufacturer take-back" legislation, and in anticipation of similar laws in the United States. Many manufacturers of durable consumer products are embracing "green product stewardship" initiatives that reach throughout the product's life cycle, from designing the product for easy recyclability to ensuring that recycling takes place.

There are no fully functioning examples of this model. The most ambitious pilot efforts are underway in the electronics industry (here including computers, printed circuit boards, electronic communication equipment, and related products). Even so, there has been ample variation in the details of each manufacturer's plan. Therefore, the electronics model is best described by the following examples of institutional arrangements, which are discussed in detail to capture the variety and level of articulation required in the institutional infrastructure.

One distinctive feature of the electronics model is the reliance on reverse logistics companies, such as Burnham Services and Equipment Recycling Services (ERS), an affiliate of North American Van Lines. These companies set up national industrial accounts that work like this: A residential or commercial customer ready to discard a product calls an 800 number provided by the manufacturer at the time of purchase.7 The reverse logistics company then pick up the item anywhere in the United States, and delivér it to the specified recovery facility. The company first may bring the product to an intermediate distribution center or storage warehouse until enough accumulates to justify a full-load shipment or route. This may entail a delay of several weeks, but that presents no problem for PVMs. The pickup charge may be paid by the generator, manufacturer, or recycler, or by a fund earmarked for this purpose accumulated from purchase revenues or advance disposal fees. Burnham and ERS/North American already have national fleets and franchises at their disposal. The reverse logistics business offers these companies ways to make money and avoid empty dead-head runs.

A closer look at the role of ERS in electronics recycling may be useful. It is a separately held company, now part of North American Van Lines' Customized Logistics Services, which, in turn, is part of North American's High Value Products Division. ERS works with clients to design a contractual, logistical infrastructure tailored to a particular

7. The number can be printed on the product label, or in product's literature. 
material or product. It has access to a very large fleet, extensive warehousing capabilities, and a network of regional distribution centers so that smaller shipments can be aggregated until full loads are obtained. ERS also has arrangements with nine processors across the United States for dismantling and recovering electronics and computer scrap, generators, and transformers. Fees depend on the material and product in question. If the product has a high secondary market value, the company may take ownership and re-sell it. But ERS normally prefers to operate in a "pass through" transfer, collection, and transportation mode. Various arrangements are made, such as commissions, to share favorable recycling prices with the original owner. "Breakage" charges can be added if ERS itself performs some disassembly to obtain glass or metal. ERS also handles any required permits, insurance, and waste auditing. Arrangements can be made with an individual company with a national installed base, or with trade associations or industry consortia.

The advantages to the original manufacturer of the equipment can be substantial. For example, Lanier used to send its used copiers from all over the United States to Florida, and then to South Carolina. This arrangement meant Lanier had to pay 60 cents per pound shipping costs in return for 10 cents per pound scrap value. Under the national account with ERS, using its regional distribution and processor networks, transportation costs are lowered drastically: Lanier pays ERS 10 cents/pound and saves 50 cents/pound.

ERS is interested in discussing possible arrangements for PVMs. Already it handles other products that call for special handling, ${ }^{8}$ such as CRTs, batteries, mercury-containing switches, and computers and electronic equipment generally.

Burnham services also is interested in discussing the collection of PVMs from residences, commercial locations such as shopping centers, and utility arrays, using an 800 call-in number. The PVMs from any rooftops must be taken down by utility personnel, as Burnham does not wish to assume the liability nor take up their employees' time in this fashion (presumably, ERS feels the same way). For large arrays, Burnham may subcontract with a partner to get extra trucks. Burnham uses the term "rollback reclamation" to describe its reverse logistics operation.

Original manufacturers of equipment can dovetail their own recovery plans with reverse logistics systems in many ways. Often, the recovery facilities accept materials derived from products made by other companies. With careful design, such dovetailing and pooling arrangements can be adapted to PVMs. If PVM manufacturers decide to

8. ERS currently is seeking an environmentally sound option for reusing or recycling of 2.5 million asphalt-impregnated cardboard artillery tubes with metal end-caps. They are taking up $100,000 \mathrm{ft} .{ }^{2}$ of warehouse space, and are too heavy for use as mailing tubes.

The CRT glass is sent for smelting to Japan, where it is reused in Coming Asahi glassware.

ERS avoids liquid and powdered hazardous materials. 
design a version of the electronics model, perhaps their best strategy (Reaven, 1994a), would be to piggyback PVM recycling onto integrated recovery systems being developed in the consumer electronics sector. Here, many elements of the ATT and IBM systems, described below, are instructive.

ATT contracts with Burnham to pick up old telephones, computers, and other items. For example, 60 old phones may become redundant as ATT installs a new telephone system in a building. The installer calls an 800 number, and gives the location, quantity, and type of materials to be picked up. ATT's volume contract with Burnham requires Burnham to pick up loads under 500 pounds and bring them to ATT's Chicago reclamation center or other specified locations. Burnham runs its New Jersey/New York City/Long Island operations from Edison, New Jersey. Once a week, a truck makes the Long Island run, collecting discards from ATT facilities and for other major clients. ${ }^{9}$

ATT also uses its own network of Phone Center Stores to recycle telephones and telephone equipment that is returned as defective, or is replaced through upgrading. These materials are sent to ATT repair centers in Atlanta or Little Rock, where they are sorted for recovery by repair, or for parts. What is left is sent to the Chicago Reclamation Center.

SONY has a reverse logistics arrangement with K-Mart and WalMart to obtain returns of defective or returned products. K-Mart sends returns in K-Mart trucks to its distribution points, where they are picked up by SONY trucks. CD players, radios, and cordless phones are brought to SONY's National Audio Equipment Repair Center in Chicago. Televisions go to the 5 or 6 SONY TV repair centers across the United States. Products are sorted, and repaired or used for parts where profitable. The remainder is sent to the ATT Reclamation Center in Chicago. ATT has an arrangement to use WalMart trucks to bring materials from certain points to the Reclamation Center. Each manufacturer's agreement with merchandisers is different.

ATT also stores its used computers, telephone housings, printed circuit boards, and other items in regional ATT salvage warehouses. ATT receives revenue from recycling and scrap vendors who collect the materials. ${ }^{10}$

ATT is exploring the possibility that some PVM materials could be processed at the ATT Reclamation Center. ATT also may be interested in collaborating with the PVM industry to arrange for collecting and recycling PVMs and ATT equipment at PVMpowered telephones and other ATT facilities, especially from remote installations.

9. Bumham also has collected (non-automotive) batteries on this run, and will accept leaky batteries.

10. Ferrous Metal Handling collects these materials from ATT's salvage warehouse in Warren, NJ. 
ATT sends materials from the Reclamation Center and other sources to five facilities around the United States for recycling. One facility is Texas Refining and Recycling (TRR) of San Antonio, which receives two 48-foot truckloads daily. TRR is comprehensive running its own recovery and precious metal refining facility (for gold, silver, and palladium), and sending breakdown items containing semi-precious metals, such as high-grade printed circuit boards, to a nearby metal refinery. ${ }^{11}$ Various other materials, including low-grade printed circuit boards, are sent to Noranda Metallurgy, in Toronto, for smelting.12 TRR will destroy otherwise resalable items, such as faulty Intel chips for proprietary reasons.

In many cases, TRR will work with a broker to find the best routing logistics and lowest prices for transporting the recyclables to them. TRR has access to a $65 \%$ discount from the broker, and can pass the savings through to the original manufacturer or other shipper. In one case, an original manufacturer of equipment who could not obtain a quoted shipping rate under 10 cents per pound, negotiated a price of 3 cents per pound by working through TRR and its broker. TRR, and other companies that recover electronics scrap, such as Envirocycle, Hallstead, Pennsylvania, offer the further advantage of relieving manufacturers of liability; for example, manufacturers need not fear that their products will pollute landfills and generate expensive lawsuits.

ATT is constructing a worldwide "ATT-approved" network for reverse distribution and recycling of its computers.

IBM operates an in-house ${ }^{13}$ version of the electronics model that illustrates what an industry-run PVM (integrated or dedicated) recovery operation might entail. They have established re-utilization and materials recovery centers in most countries which handle 30,000 tons annually of discarded computers (from internal corporate use, expired leases, surplus, and obsolete machines), sub-assemblies and components from IBM production plants, and some general equipment scrap.

At present, this program captures a small percentage of discarded IBMmanufactured computers. However, voluntary IBM take-back programs are underway in Switzerland, Germany, Italy, the United Kingdom, Austria, France, Sweden, and the Netherlands, in response to existing or expected legislation in individual countries and

11. One strategy to make recycling of PVMs more attractive could be to deliberately incorporate materials with high recovery value, such as gold. While this might raise production costs, the overall lifecycle costs might be lower.

12. A large fraction of North America's low-grade semiprecious-metal electronic scrap winds up at Noranda, one of a few smelters anywhere suited to process these materials into refined copper, precious and semi-precious metals, and lead.

13. Digital Equipment Corporation's Resource Recovery Center in New Hampshire handles DEC's internal retum and reclamation program for used computer terminals, with transport and final recycling carried out by external contractors. 
the EU. Customers pay, shipping costs according to weight-based fees set for each class of equipment. With the take-back programs contribute a small percentage of the discard stream entering the IBM recovery centers, ${ }^{14}$ ' it should climb as more consumers participate, and as recent generations of computers are replaced. IBM is preparing similar programs in the United States.

The labor-intensive recovery centers segregate and dismantle the discards, remove useable parts, and reduce the rest to materials streams - ferrous and nonferrous metal, circuit cards, CRTs, paper/cardboard, plastics, and hazardous items (such as batteries). ${ }^{15}$ Scrap iron (60\%), plastics ( $9 \%$ ), and non-ferrous metals $(8.5 \%)$ are the predominant streams produced. As the stream of discards from older machines dies out, the percentage of steel should drop substantially. The streams are sold to "IBM Certified" recyclers.

Only the CRT glass, plastics, and hazardous items do not yield a net financial return. For plastics, the multiplicity of resins (mainly acrylonitrile butadiene styrene, high-impact polystyrene, polycarbonates, other polystyrene, and polyvinyl chloride $15 \%$ of computer plastic scrap is unidentifiable or contaminated) and the variety of compatibilizers, coatings (particularly metallized ones), colorants, and other additives, have been troublesome. ${ }^{16}$ However, revenue from profitable materials can offset losses from unprofitable ones. This may or may not work for PVMs (Reaven, 1994a).

14. IBM Deutschland's corporate computer recycling rate in 1994 was $83.6 \%$; this represented 3,479 metric tons of leased or internally used computers, and 708 metric tons purchased from customers, at an average return fee of DM50.

15. The problem with CRTs is their lead, two to three pounds, which is one fifth the weight of the glass, per typical CRT, which makes them hazardous. The demand for leaded glass is weak. As noted, Corning Asahi uses CRT cullet provided by Envirocycle. Noranda is considering shipping CRT glass to a lead smelter it operates to recover lead, and use the silica as a flux substitute in separating off slag. circuit boards.

Tin-lead solder, while small in volume, similarly complicates the recovery of metals from printed

From $15 \%$ to $20 \%$ of the internal components of computer are plastic, versus $50 \%$ to $60 \%$ for external housings [Wigotsky].

16. In early 1995, Bruker Instruments, Billerica, Massachusetts, announced they had developed a hand-held device that scans plastic items and identifies the resin in five seconds. A prototype is under test at the automobile industry's Vehicle Recycling Development Center in Highland Park, Michigan. Such technologies probably will decisively improve recycling operations and the economics of recovery for plastics in durable consumer products.

IBM (United Kingdom) and its manufacturing partners, HydroGeon and the Mann Organization, developed a process to remove PVC feedstock from end-of-life computer keyboards and to compound it into a $100 \%$ post-consumer recycled grade suitable for use in monitor bases and new keyboards, at a $22 \%$ savings in raw material costs. This is the first significant instance of closed-loop recycling for computers. 
The PVM industry may adopt the idea of developing a cachet for its network of dismantlers and recyclers; e.g., "PVM Manufacturer Certified Recycler."

IBM stated that it wants to develop collaborative programs with other original equipment manufacturers, suppliers, and reclaimers.

Some recycling entrepreneurs collect and recycle used electronic equipment largely independently of arrangements with individual manufacturers, concentrating on precious metals, glass, component sales, low-end co-mingled or composite applications, and resale of functional older machines for export and other secondary markets. ${ }^{17}$ in some cases, usable older machines are given to schools (this can count as a charitable tax deduction). Some entrepreneurs send computers overseas for lowcost manual sorting.

For optimum economics, dismantling, sorting, grinding, and cleaning operations should be collocated (in principle, this also applies to the recycling steps) ${ }^{18}$ but, few operators have all the technologies in one facility. Special market development zones for recycling might overcome this obstacle, by conferring tax benefits, securing lowinterest loans and access to venture capital, exploiting economics of scale from shared sorting facilities, and lowering transportation costs. The State of California has sought to create such zones.

The PVM industry should watch developments in integrated dismantling facilities that do not concentrate on the electronics products; e.g., the Multi-Product Recycling Facility sponsored by the American Plastics Council and wTe Corporation in Boston, the Highland Park, Ml, experimental facility of the Vehicle Recycling Partnership, and a project now being considered by the National Center of Manufacturing Sciences to design recycling systems for various durable consumer products. There may be options for dismantling PVMs in such integrated facilities.

17. Advanced Recovery, inc., of Belleville, NJ, is a large computer and electronics scrap recycler that receives 400,000 pounds/month of used computers. In 1993, the company charged $\$ 500 /$ truckload for office pickup. Advanced Recovery claims to recycle the "whole unit from the tiniest bolt to the entire plastic casing." it also buys integrated circuits, semiconductor chips, and circuit boards; it pays $\$ 0.05$ per pound for most electronic devices. However, it charges commercial generators $\$ 15.00$ per CRT ( $\$ 8.00$ for homeowners), and offers volume discounts of $50 \%$ to businesses for up to 30 CRTs. Conceivably, these elements could be adapted to a pricing structure for a PVM dismantlement operation. Advanced Recovery strips CRTs in two hours. Units that are serviceable are shipped to China, Russia, and other countries.

18. Transportation costs are not always proportional to distance. The greatest backhaul discounts are obtained on the longest moves (including international ones) [Watts, 1994]. The cost-per-mile for truck shipment of paper for reçycling from Los Angeles is 2.04 to Las Vegas, 0.27 to Chicago, .14 to Newark, and .05 to Taiwan. Stand-alone (i.e., to-order trips with no guarantee of a return load) truck rates are $\$ 2$ per mile and up, but rates for recycled products consistently are below $\$ 1 / \mathrm{mile}$, taking advantage of backhaul discounts and other opportunities. 
One institutional issue that affects some materials and products is that of determining when an item becomes regulated as waste of one kind or another (or as waste at all). For example, broken CRT glass is hazardous in some states, not in others. EPA rulings vary'from region to region; e.g., the reuse of leaded cullet from demanufactured CRTs. Similar questions were raised about the regulatory status of printed circuit boards: do they become waste when taken from computers or when they are shredded and ground? The economics of recycling computers could disintegrate if whole computers or computer scrap is classified as hazardous.

Industrial waste exchanges may have a place in the institutional infrastructure for recycling PVMs. They advertise for fluorescent ballast, specialty glasses, metals and metal sludge (including wastes from circuit board industries). Some electronics recyclers obtain materials from waste exchanges.

One experimental technological approach to recycling electronics and other durable consumer products may be worth investigating for its possible application to PVMs within an integrated processing operation. ${ }^{19}$ Hitachi Limited, Tokyo, is building a pilot cryogenic facility in which products will be supercooled, fragmented, and sorted. After metals are removed, the residue will be crushed at $-20^{\circ} \mathrm{C}$ to facilitate separation of plastics.

Germany is committed to extending the general "manufacturer take-back" approach of its earlier (1991) Ordinance for the Avoidance of Packaging Waste to include durable goods, beginning with automobiles, electronics, and construction and demolition debris. The packaging take-back law led industries and retailers to organize a non-profit, third-party instrumentality, Duales System Deutschland (DSD). Manufacturers pay licensing fees to DSD based on the weight, volume, and material of product's packaging. In exchange, their products are allowed to display the Green Dot or the Blue Angel ecolabels.

This law has engendered high costs and has generated large market surpluses, especially for plastics, much of which has had to be exported. On the other hand, the $\$ 1.9$ billion spent by DSD in 1993 diverted $57 \%$ of residential packaging wastes, and the concomitant changes in product design are said to have averted another $13 \%$ through source reduction:[van der Linde 1994].

The extension to electronics and other durable goods will take effect in 1995, but implementing regulation may be postponed. Many observers agree that industry has little idea of how to proceed, despite several promising experiments. "They don't have a clue on how they're going to handle it," according to TRR's M. Filandro [Borsecnik 1995]. Approaches vary in other European countries (and in Japan), although the

19. Reaven (1994a) identified several other technologies with a potential for PVM recycling. 
German system is expected to be a model for many. ${ }^{20}$ The European Union is to promulgate similar take-back guidelines for electronics, automobiles, and construction materials by mid-1995, with Italy, France, and Germany, respectively, taking the lead roles in formulating guidelines. ${ }^{21}$ There is little prospect that the schedule will be met.

Existing government-sanctioned ecolabeling programs in Europe are being extended to electronic goods, allowing a Green Dot, Blue Angel, or other identifier to be used, in exchange for complying with whatever the take-back regime proves to be. Many observers think that a similar ecolabel approach will take hold in the United States, as it has with NiCd batteries. This approach may be combined with one in which the original manufacturers of the equipment buy back the used computer or give the customer credit towards purchasing a new one, turning over the used computer to the recycler, and paying a processing fee. All costs would be recovered in the price of a new computer. Some of these ideas are embodied in the battery model (see below).

\section{THE UTILITY MODEL}

In this end-user oriented model, utilities anchor the PVM recycling infrastructure by arranging to recycle modules in their own arrays, and by directly or indirectly arranging to recycle modules on institutional rooftops and homes. Utility employees would remove old residential, commercial, and utility installation PVMs from rooftops or other mountings, collecting when called, using the utility's trucks. ${ }^{22}$ Collecting PVMs

\footnotetext{
20. Some recent developments: Sweden. $A B$ Gotthard Nilsson and Ragn-Sells $A B$ created a new company, Gotthard Ragn-Sells Elektronikatervinng $A B$, that began dismantling and processing electronics in the summer of 1994, under contracts with IBM, Siemens Nixdorf, Canon, and other companies. Japan. Televisions, washing machines, refrigerators, and air conditioners must be designed for easy recyclability under a new law. Matsushita developed a television that can be disassembled by removing four screws. Italy. From June 1994, manufacturers of television sets and certain other household equipment must collect them for recycling, reprocessing, or disposal. United Kingdom. The Industry Council for Electronic Equipment Recycling is sponsoring three trial projects to collect and recycle residential and commercial discards. Germany. Among the existing schemes for collecting and processing electronic goods is Elektro-Gerate-Recycling $\mathrm{GmbH}$, a national program sponsored, in part, by manufacturers Miele and Liebherr. Also, Siemens Nixdorf became the first computer maker authorized to display the Blue Angel ecolabel, indicating that the product was designed for easy re-use or recycling. [Orton, 1995].
}

21. France's national automobile recycling program is organized around the infrastructure of the junkyard/auto scrap dealer. Participants in the voluntary Green Salvage Yard Plan establish a network of collection points for waste from scrap cars, including used oil, batteries, and tires. A six-month to oneyear program of training and investment is required for a salvage company to qualify for certification that entitles them to display an eco-label showing a dismembered car surrounded by the now de rigueur chasing arrows. The goal of the plan is to recycle or outfit for reuse $95 \%$ of discarded automobiles [Kulik 1995]. Ordinances embodying the plan were scheduled to be promulgated in late December, 1994.

22. Utilities could make special arrangements for other options, such as pick-up of larger quantities of PVMs that customers drop-off at Home Depot centers. 
becomes a standard function of the utility, like reading meter, repairing lines, and removing trees.

The rationale is compelling. Utilities will be the largest single PVM end-users. They have considerable transportation equipment, including repair trucks and other vehicles that stop at homes and buildings anyway, and that could carry used PVMs on return trips. Cherry-pickers, ladders, tree-trimming, brush-removal, and storm-damage repair equipment, combined with ongoing safety training programs, make the utilities very well suited to perform rooftop dismounting. Moreover, PVM disposal services would be a logical extension of the utilities' energy conservation, retrofitting, and solarization programs. Clean Air Act Amendments benefits accrue from avoiding pollution from fossil-fuel units, and from using PVMs in recharging electric vehicles, commuter-station units, and remote units. Load management also benefits in terms of meeting peak demand, reducing grid construction, and controlling power quality control. Citizens benefit from lower power rates and reliable, nonpolluting energy.

What is more, utilities already have significant experience in waste management from nuclear, coal, oil and ash management. Indeed, there may be opportunities to mix PVM materials streams with ash from coal-fired or MSW-fired electrical generation facilities, for example, in ash-based construction blocks. Ashfills themselves could be disposal venues for some PVM materials with concentrations of heavy metals.

The utilities with active solar programs that we contacted have not attempted to design a recycling program for PVMs, and have no end-life plans. However, the New York Power Authority's plans illustrate the scale of the opportunities. Its Southeast New York (SENY) division plans to install $5 \mathrm{MW}$ of roof-mounted PVM systems between 1995 and 2000 for its institutional customers ${ }^{23}$; the 1995 target is to install 8 roof-mounted $30-40 \mathrm{kw}$ systems (300kw total). SENY also seeks to induce a manufacturer of thin-film, crystalline, or polycrystalline PVMs to build a plant in the region in exchange for an assured market of $2 \mathrm{MW}$ in modules annually for five years. NYPA would purchase one-half for using in NYPA-served installations; the other 5MW would be purchased by other utilities in New York State, the United States, or overseas, with NYPA agreeing to be the purchaser of last resort if sales do not materialize. NYPA projects a level cost for PVM-derived electricity of 20 cents/kwh in 2000, 10 cents/kwh in 2010.

23. NYPA serves mainly state government buildings in SENY. The total roof area of the 1,000 largest state government buildings in the SENY region is thought to be approximately 30 million $\mathrm{ft}^{2}$, including universities. If $40 \%$ of the area is covered with arrays, the capacity would be $160 \mathrm{MW}$. Public school buildings on Long Island present enough roof area to provide another $100 \mathrm{MW}$. At an $18 \%$ capacity factor, each $\mathrm{kw}$ of PV system in SENY would generate an average of $1560 \mathrm{kwh} / \mathrm{year}$. The largest PVM system in New York State is the $90 \mathrm{kw}$ array at the State University of New York, Farmingdale, Long Island. This may be a useful site to try out dismounting, disassembly, and other logistical operations. The projected 260MW of PVM capacity in SENY also could form the basis of case study to estimate disposal rates and end-life collection scenarios. Large arrays, such as the AmocoEnron project to construct a $100 \mathrm{MW}$ solar electric plant in Nevada, would be examined in such a case study. 
NYPA expects to charge for electricity from PVMs at the same delivered price as that from conventional systems, less a $10 \%$ discount during the first five years to attract participants. The Authority would own, operate, and maintain the modules for their entire 20-year expected lifetimes. It is hoped that this experience will lead to progressively lower installation costs (for the $300 \mathrm{kw}$ planned for 1995, NYPA estimates such costs at $\$ 9,000 / \mathrm{kw}$; the 5 -year goal is an average cost of $\$ 4,500 / \mathrm{kw}$ ).

Similarly, NYPA might use their experience in dismounting, disassembling, collecting, and transporting end-of-life PVMs progressively to reduce the attendant direct costs.

A major advantage of the utility model is the availability of tax-exempt financing for environmental projects, including solid and hazardous wastes recycling and waste disposal facilities, and ancillary projects. The Internal Revenue Service defines these terms quite broadly, so that a PVM-related recycling and/or dismantling facility is likely to qualify. The 1986 Tax Reform Act also made privately owned facilities for hazardous waste disposal eligible for tax-exempt financing. When such financing is unsuitable, so-called project financing can be an attractive alternative [Solsky and McCarthy, 1995].

There are likely to be other financial advantages under the provisions of the Clean Air Act Amendments, both from avoiding pollution that otherwise would be generated by conventional power plants, and from reducing pollution associated with using electric vehicles recharged by photovoltaic modules, particularly at employee parking lots or commuter rail parking lots.

The institutional infrastructure being developed to recycle fluorescent lights and ballasts also is worth studying as an example of utilities playing a leading role in recycling, working with institutional generators of these discards.

The utilities' experiences with recycling fluorescent lamps suggests contractual and logistic options. Minnesota law requires utilities to collect for recycling any fluorescent lamps that are discarded in programs for energy conservation and load management. Northern States Power has incorporated this activity in its conservation programs, including giving rate discounts and financing assistance to customers. Minnesota businesses that want to discard fluorescent lamps contact recyclers (there are two in Minnesota) who transport them from the generator to a recycling facility. Household fluorescents are consolidated at city or county drop-off sites, and at some retail hardware and appliance stores. Recycling fluorescent lamps also may be eligible for some benefits under EPA pollution prevention programs, such as its Green Lights program. 
The recycling of PCB ballasts from pre-1979 fluorescent tubes, as they are removed in utility commercial light in retrofit programs, is a related example. 24 in the system developed by FulCircle Ballast Recyclers of Bronx, New York, ballasts are removed from fixtures and placed in drums, trucked to FulCircle, and dismantled. The resulting material streams are sent to smelters (copper), mills (aluminum and steel), and incinerators (PCB capacitors and contaminated asphalt potting material). Public Service Electric and Gas is one customer. Reliable markets for the recovered tube glass are elusive. DOE's Pantex plant also has arranged to recycle its fluorescent tubes.

Utility planners should meet with PVM industry representatives to study (a) ways in which the costs of PVM recycling might be financed through rate structures, a labeled fee on utility bills, or a rebate on a prepaid disposal fee, and (b) financial benefits from integrating into retrofit and energy conservation programs, pollution prevention programs, and compliance with the Clean Air Act.

In theory, rates for electricity from a utility's PVM arrays could vary slightly as the recycling markets for modules fluctuate. This rate structure is analogous to the variable rate structures enjoyed by many aluminum producers, who pay above-market prices for electricity when aluminum prices are high, and below-market prices when they are low.

The PVM industry should explore opportunities with manufacturers, NYPA, private utilities, the Northeast Regional Community Environmental Center (a utilitysponsored consortium), the Edison Electric Institute, the Electric Power Research Institute, the National Renewable Energy laboratory and similar institutions. For example, the PVM manufacturing facility sought by NYPA could be the nucleus of a recycling industry park, situated on abandoned land slated for "land recycling."25 The benefits could include attractive electricity rates, the creation and retention of jobs, and national and global markets.

\section{THE BATTERY MODEL}

In the battery model, a consortium of manufacturers oversees a take-back program that uses dedicated collection and recycling facilities. The project is financed through member dues to the consortium, licensing fees, or other mechanisms.

24. A 48" fluorescent tube contains between 15 and $70 \mathrm{mg}$. $\mathrm{Hg}$ in coating materials. Most end assemblies made before 1979 contain PCB ballasts holding about an ounce of PCB fluid. There are between 400 million and 1.6 billion ballasts still in service. A $100,000 \mathrm{ft}^{2}$ building holds between 2,000 and 3,000 ballasts.

25. This siting strategy offers several advantages, and can be used to help commercialize other recycling and waste minimization technologies (Reaven, 1994b). 
The best example of the battery model is the program for recycling portable rechargeable NiCd batteries. Three to four hundred million NiCds were sold in 1992, more than $10 \%$ of overall U.S. battery sales. Most are used in consumer products such as cordless telephones, camcorders, power tools, two-way radios, and laptop computers; since 1993, most of these products have been redesigned so the NiCds are easier removal to remove. Only $10 \%$ to $20 \%$ of NiCds are the cylindrical alternatives to the familiar alkaline or carbon-zinc batteries. Nearly one-half of NiCd production is sold to business and industry customers.

Prodded by laws in New Jersey, Minnesota, and in Europe, and by the prospect of similar regulation elsewhere, ${ }^{26}$ five major NiCd manufacturers; Gates Energy Products, Panasonic Industrial Company, Sanyo Energy (USA), Varta Batteries, and Saft America, Inc., formed the Portable Rechargeable Battery Association (PRBA) in 1991. Smaller manufacturers, product makers, and battery pack assemblers have joined since; there were 116 members by the end of 1992. They represent more than $90 \%$ of NiCd manufacturing capacity worldwide (and 60\% of SLA capacity), and have the lion's share of rechargeable consumer products.

PRBA later formed the non-profit Rechargeable Battery Recycling Corporation (RBRC) to conduct the NiCd recycling program. Manufacturers pay license fees that fund the program, and confer the right to place the RBRC seal on batteries and products. Commercial and institutional generators register to participate in the recycling program, and agree to return spent NiCd batteries to designated consolidation facilities or directly to International Metals Reclamation Company (Inmetco), the recycler, in Ellwood City, Pennsylvania. Similarly, batteries also are collected by retailers, cities, and counties.

The current national expansion of the RBRC program amalgamates four collection infrastructures:

1. City and county. Batteries accumulate at county and municipal collection centers, either by individual drop-offs or from collection at residential curbsides. They are transported from the; collection centers to Consolidation Points. ${ }^{27}$ Under a contract with RBRC, the operations of Consolidation Points perform any required additional sorting and send bulk shipments to Inmetco. ${ }^{28}$

26. The difficulty in reducing cadmium content in nicads also contributed to the emphasis on recycling.

27. Wade Environmental Industries, Battery Division, Atco, NJ, and U.S. Filter, Roseville, Minnesota. RBRC plans to have a West Coast facility available soon.

28. As of 1993, Inmetco was the only American recycler that PRBA found equipped and willing to accept the nicads. Inmetco recovers the nickel, and sends cadmium-bearing process waste elsewhere; prices are negotiated on each contract. PRBA also looked for other potential processors, including ones in France and Japan. 
The RBRC pays for transport from the county and municipal collection centers, and for the recycling charges. The battery industry does not fund the original city or county collection.

2. Reverse retail. RBRC sends participating retailers ${ }^{29}$ a recycling kit consisting of a point-of-sale display, plastic Zip-loc bags, handling and safety instructions, and four folded-up collection boxes that can hold 18 pounds of NiCds. The retailer sets up the collection boxes, and when full, seals them with tape. The boxes come with pre-paid UPS shipping label pre-addressed to Inmetco. RBRC is seeking approval for the reverse retail program in all states.

At Inmetco, weight and other shipment information is entered into a computer. RBRC has purchased an automated shipping system that, beginning on May 1, 1995, will use lasers to scan bar-coded boxes arriving at Inmetco. When the third of an individual retailer's original four boxes arrives, an empty box automatically will be shipped from Inmetco to the retailer to ensure a constant supply of boxes at both ends, and to reduce the inventory "float" in boxes. The automated system will be able to store 80,000 boxes from the United States at any time.

This system is tied in with an automated voice-response system at the PRBA offices in Atlanta. Anyone calling 800-8-BATTERY, is told the location and telephone number of the nearest county or municipal collection center, and of up to three nearby participating retailers. Instructions are given for disposing of non-NiCd batteries, too. If there are no collection centers or retailers nearby, the caller is given a mailing address in Pennsylvania where Inmetco makes periodic pickups, and instructions on shipping the batteries there. Shipping charges are paid for by the individual caller; RBRC does not use pre-paid mailers. ${ }^{30}$

29. Participation is required in New Jersey; it is voluntary in other states. Manufacturers' service centers also can count as retailers. In the original Battery Management Plan filed by PRBA and approved by the State of New Jersey, distributors had to accept from retailers the same kind of household batteries they distribute, return them to the Consolidation Point, and then would receive reimbursement for freight costs from the operators of the Consolidation Point. In the New Jersey plan, independent collectors also were allowed to return batteries, at their own expense, unless PRBA (then, the sponsoring body) made a special agreement to the contrary. Conditionally exempt small-quantity generators and institutional generators could opt out of the PRBA plan if they develop approved in-house management plans. The authors have not determined the status of such variations under the national RBRC plan.

New Jersey also created special provisions for phasing out mercuric oxide batteries generated by hospitals and nursing homes, working through the National Electrical Manufacturers Association.

30. Some individual companies, such as Skil, Makita, and Black and Decker, provide pre-paid mailers, addressed to Inmetco, for batteries used in their products. This is a very expensive, inefficient ways to collect batteries. Mail-back costs can be $\$ 4$ per battery. 
RBRC authorized a $\$ 1.6$ million advertising budget targeting retail associations and trade publications. Retailers will be encouraged to call a toll-free number where interactive software explains the recycling program and then signs up retailers who decide to participate: a warehouse in Pennsylvania sends out boxes the next day; Radio Shack among others has signed up.

3. Commercial and institutional generators. Manufacturers, police, fire and emergency service operations, and other commercial and institutional generators participate in the RBRC program by agreeing to collect their discards and ship them, at their own expense, to the nearest Consolidation Point. However, RBRC then pays the costs for consolidating them into larger shipments transporting to Inmetco, and for recycling (about 40 cents per pound). The generators and consolidation facilities exchange liability waivers and mutual indemnification.

A dedicated toll-free phone number with interactive fax capability has been set up to recruit commercial and industrial participants. Callers can select the information they need to receive via fax: State governments also can ask the system to pass along desired information to callers.

4. Licensee rebates. Licensees pay for the right to display the RBRC seal on their products. If these manufacturers arrange and pay for collection and shipment of batteries to Inmetco (not to consolidation points), they receive a rebate of 17 cents per pound from RBRC.

RBRC operations and associated parent PRBA programs are financed out of member dues and assessments, licensing fees, and cost-sharing agreements among manufacturers. In coming years, statistical studies will be used to adjust contributions so that costs are fairly allocated in rough proportion to each manufacturer's percentage of the battery stream. Terms of some agreements to share program costs between state agencies and individual manufacturers or industry sectors are confidential. The PRBA and RBRC maintain an interest in exploring alternative financing mechanisms; these could include per-unit surcharges, and advance disposal fees.

The current RBRC plan reflects lessons learned in experiments in New Jersey and Minnesota, where novel legal and infrastructural challenges had to be met. For example, in New Jersey, preparing a contract for the statewide consolidation facility was a complex matter, owing to environmental requirements. Other issues concerned the degree to which manufacturers would have to sort out non-NiCd batteries, the wisdom of mingling $\mathrm{NiCds}$ from all residential and commercial generators (to allow larger shipments), and the point at which the battery industry would assume legal responsibility for commercial and industrial discards. Uncertainties about the status of the RCRA Subtitle $C$ hazardous-waste characterization for non-household NiCds, under TCLP criteria, and about conditional exemptions for small quantity generators, also complicated cost projections. Cohen (1993) estimated that the program would cost $\$ 600$ million less without the hazardous waste classification for $\mathrm{NiCds}$ than with it. 
In New Jersey, battery manufacturers must collect discarded batteries (in Minnesota, manufacturers of batteries and of products containing them must collect the batteries, and the products too, if the batteries are not removable). Manufacturers must file a battery management plan that provides for consumer education and semi-annual reporting, among other things. The unofficial state goal is an $85 \%$ capture rate. Other states have considered mandating deposit systems or advanced disposal fees. In an early pilot program in metropolitan Minneapolis, battery manufacturers paid a management service fee ( $\$ 300 /$ month) and a battery sorting fee (25 cents per) to the county.

Some battery manufacturers are developing recycling programs for non-NiCd batteries. For example, Eveready entered into an agreement with Drinkard Metalox Co., Charlottesville, Virginia, to recycle its alkaline batteries. A recycling plant is scheduled to begin operating near the turn of the millennium. The logistics of collection and financial responsibilities for transporting and recycling are under discussion. Eveready prefers municipalities to collect the batteries (ideally in yellow Zip-loc bags that garbage truck drivers keep on hand for use, as in Warren County, New Jersey). Eveready also prefers transporting the batteries by rail because they can be poured easily from the bottom of the railcar at the destination.

Rechargeables can be recharged 300 to 1500 times; comparable nonrechargeable alkaline batteries are several hundred times more expensive for the same number of service hours. On the other hand, their high self-discharge rate makes rechargeables unsuited to some applications. In Germany, $40 \%$ of household dry-cell batteries are bought for portable audios, $21 \%$ for toys and games, $17 \%$ for flashlights, $12 \%$ for cameras, and $10 \%$ for other purposes [van der Linde, 1994]. In 1994, European (including German) battery producers strongly fought the proposed requirements of the European Union and of individual countries to require recycling and a tax or deposit on all dry cell batteries. However, NiCds are collected and recycled in Germany and some other countries, pursuant to a 1988 voluntary industrygovernment agreement. Estimates of Germany's NiCd recycling rate in the early 1990s are conflicting, and levels of $50 \%, 35 \%$, and $28 \%$ have been reported [van der Linde, 1994].

The recycling rate strongly affects the economic viability of the recycling program and the relative attractiveness of separate (i.e., NiCd only) versus mingled battery collection. NiCd rechargeables were recycled in a French plant for $\$ 2,900$ per ton (not counting the cost of prior sorting from other batteries); however, costs might drop to $\$ 1,500$ per ton with significantly higher return rates. Some observers believe that NiCds eventually will be banned outright, or so heavily "eco-taxed" to become rare, as new generations of environmentally superior battery technologies arrive.

Van der Linde (p. 22) notes an ironic consequence of the concentration on the development of "green" batteries: "producers had encouraged consumers to think of 
batteries as potentially harmful products." This double-edged sword also could fall on the PVM industry.

The widespread use of PVMs to recharge NiCds and other rechargeables could link the utility model to the battery model.

A different institutional regime governs automotive sealed lead-acid (SLA) batteries; $94.4 \%$ of the 87.8 million lead-acid batteries used annually are recycled (metals, plastic cases, and chemicals are recovered). The average life for passenger car batteries is four years. Producing these batteries consumes $80 \%$ of the lead used in the United States.

Forty-two states (and one city) have enacted recycling legislation for lead-acid batteries. Eight of these states require a $\$ 5$ deposit per battery in lieu of a trade in, and two have a $\$ 10$ deposit. In a few other states, retailers must levy a $\$ 2$ or $\$ 3$ charge (this is not a deposit) for batteries they sell or collect (in Rhode Island, there is a $\$ 1$ handling fee). The fraction of the deposit or collection fee retained by the retailer varies drastically. Remaining revenues typically are assigned to recycling activities.

The Institute of the Scrap Recycling Industry (ISRI) supports the extension to SLA automotive batteries of manufacturer take-back programs and minimum recycled content legislation, partly to increase demand for secondary lead. ISRI proposes creating a marketable credit system that would let battery manufacturers exceeding the recycled content minimum to sell credits for the tonnage of secondary lead they use above the standard to other manufacturers whose product falls below the minimum [ISRI 1994]. This trading pool would resemble the emissions trading market sanctioned under the 1990 Clean Air Act Amendments. ISRI also is concerned about potential Superfund liability for cleanup costs associated with remediation of smelter contamination, and about the potential assignment of liability to the recyclers who collect the batteries for shipment to secondary smelters. Many recyclers have avoided handling SLAs for this reason.

\section{OTHER IDEAS}

During our research we found some intriguing practices were that belong in the table of options for further consideration in designing the PVM recycling system, but which cannot be identified with any one of the three paradigms discussed above. We also note that the institutional infrastructures for recycling aluminum, glass, and tire recycling are not suited for recycling PVMs. However, because of their intrinsic interest to reycling options, we mention them in the footnotes. ${ }^{31}$

31. Glass, aluminum, and bulk metal scrap industries offer few institutional infrastructure lessons for PVM recycling. The huge volumes, marketability, specifications, known reliable supply sources, heavy investment in equipment, and known recycling technologies, not to mention the clear savings in production costs associated with the large-scale uses for the recycled materials, allow everyone involved 
(primary and secondary recycler, breaker and broker) to make money, without inordinate regulatory oversight. Descriptions of institutional infrastructures for aluminum, glass, and tires follow.

ALUMINUM. Aluminum recycling is distinctive because the manufacturer often is the recycler, due to the closed, fast recycling loop in its beverage-can sector, and the reliable, high-volume, high-value discard stream. These very qualities mean that aluminum recycling holds little value as a model for PVM recycling.

Aluminum beverage-can recycling has had an uneven history, one that continues to be marked by major price swings, inventory fluctuations, and vulnerability of exports and imports to world market conditions, since the first Reynolds trials in 1967 [McCutcheon 1992, Kuster 1993]. Still, an intensive information campaign and widespread deposit refund programs of various types have led to recycling rates above $60 \%$ in the 1990 s. Aluminum cans hold $96 \%$ of the beverage-can market. Manufacturers purchase discarded cans, on a per-pound basis, from the 10,000 or so collection centers in the United States. The can-to-can round trip averages 6 weeks. Some companies, such as Reynolds, use their own network of fixed and mobile collection centers. Others, such as Alcoa, emphasize working through scrap dealers (and can-manufacturers, to encourage process conversion). There is an active export market in used beverage containers.

Secondary aluminum supplies $30 \%$ of the annual U.S. aluminum demand. New aluminum plants can make aluminum from ore as cheaply as from used beverage containers; the savings come in transportation (and from reduced need for additional plant capacity). (Cans also were downsized 32\% between 1972 and 1991.) Primary aluminum makers are supplemented by 12 or so secondary smelters and many smaller remelting operations. Together, these maintain large market for used cans. At prices below 48 cents per pound, secondary smelters can afford to remove magnesium from can tops and enamel paint from can walls. The industry also has programs for recovering of foil wrap and aluminum foil containers.

Sweden's deposit refund system for aluminum cans is distinctive. The beverage, packaging, and retailing industries created the system to avert bans or other restrictive laws. The return rate is $85 \%$, the worlds' highest. In North American deposit systems, the deposit originates with the bottler or distributor. In Sweden, it originates with the cans' manufacturer (or beverage importer). Retailer participation is voluntary in that they must collect the deposit, but need not redeem containers. For most drinks, the container's manufacturer pays the deposit into a fund. The deposit follows the can through each step. When the consumer obtains a refund from the retailer, the brewery pays the retailer a deposit (and a small handling fee). When cans are delivered to the recycling facility, the brewer gets the deposit back (and small fees for handling and collection). Brands are not separated since the deposit starts with the manufacturer of the cans. The system is financed from unclaimed deposits, floating interest on deposits before redemption, scrap aluminum sales, and administrative fees. Expenses for the system include marketing, renting freight and containers, an environmental fund, and administrative costs. [Franklin 1993].

GLASS CONTAINERS. Owen-Brockway, the industry leader, and many other major glass container manufacturer no longer process cullet. Because they want to concentrate on making bottles, not on controlling feedstock contamination and processes, cullet processing is contracted to third-party (intermediate) processors. Manufacturing plants in 27 states make 41 billion glass containers annually (64\% clear, $23 \%$ amber, $13 \%$ green); $35 \%$ of them are recycled. Some 60 processor plants make furnace-ready, beneficiated cullet; some make fine-ground powder for the fiberglass industry. OwenBrockway alone uses $46 \%$ of the cullet recovered by the container industry, and produces $30 \%$ of the country's glass containers. The market is highly variable; for example, in May 1992, prices for flint and amber glass dropped from $\$ 40$ to $\$ 21$ per ton. Commingled collection also is problematic, due to breakage and pieces of glass that end up in mixed color residues. Cullet is bought from materials recovery facilities (MRFs) and buy-back centers (at $\$ 30$ per ton in 1994). Legislation on recycled content also is taking effect: for example, in Oregon, glass containers must be at least $35 \%$ post-consumer by 


\subsection{Retail-Based Collection at Home Depots}

In 1993, the Home Depot chain began experiments at some outlets with a "do-ityourself" Recycling Depot program, in a joint venture with Mindis Recycling, a division of Attwoods ple (the world's fourth-largest waste management company). Homeowners and business customers, such as plumbers and small contractors, bring gutters, electrical wire, water heaters, screen doors, plumbing parts, and other (mostly aluminum) metal scrap to a drive-through facility on the Home Depot lot. They are paid for the metal or can set up an account, and have the option of assigning revenues to charity. The pilot facility in Georgia was expected to recover 500 tons/month. Plans were being considered to add roofing debris, paints, and other construction materials that are difficult to recycle to the program. Sears has considered setting up on-site recycling centers.

Something like the Home Depot/Mindis arrangement ${ }^{32}$ clearly is worth considering for PVMs, which are likely to be sold at Home Depots or similar stores. Some PVMs will likely be discarded from remodeling and demolition work. If the customer cannot be paid for dropping off the end-of-life PVM, it may be possible to give

a certificate good for a discount on a new module. We recommend that the PVM industry discuss possible arrangements with Home Depot and Mindis/Attwoods.

\subsection{PVM Collection by Commercial Glass Trucks}

PVM manufacturers or trade associations might make arrangements for plateglass installers to pick up PVM discards from commercial installations, such as roofs of shopping centers. For example, the next time new panes are delivered to the shopping center, the dismounted PVMs could be carried back on the empty truck. They could be

1995; California requires an escalating content, rising to $65 \%$ by 2005 . Better specifications for cullet are being developed.

TIRES. Thirty-three states fund scrap tire programs via disposal fee or tire tax; fees are 0.25 to $\$ 2.00$ per transaction. Funds typically are earmarked for programs for tire collection and storage, and cleanup of abandoned tire piles, and generally do not go to recycling businesses. Eleven states offer tax credits to businesses, ranging from $10 \%$ to $40 \%$, to start or increase recycling. The credits apply to purchasing processing equipment and using secondary materials. Oklahoma and Texas pay processors 85 cents per tire processed. Idaho, Utah, and Wisconsin offer rebates to end-users (between $\$ 20$ and $\$ 65$ per ton). Eighteen states extend price preferences of $5 \%$ to $15 \%$ for using products from recycled tires; thirteen states have "buy-recycled" procurement programs [Sikora, 1994]. Some of the procurement and other benefits apply to the use of rubberized asphalt. Reaven 1994(b) gives addition information on tire recycling.

32. Conceivably that PVMs could be collected by community-based facilities that dismantle other goods, such as mattresses and other home furnishings. Boone (1994) describes a county-sponsored facility in Oakland, California. Bronx 2000 also has ventured into this area. 
delivered to a designated collection site, turned over to a reverse logistics carrier, or held at the plate-glass shop until sufficient PVMs have accumulated.

\subsection{Cooperative Marketing}

Cooperative marketing refers to organizations created jointly by governmental authorities and various private businesses, especially in rural or low-population-density areas [Luck and Olson, 1992]. Forty to sixty per cent of operating funds come from service fees, the rest from grants, in-kind contributions, and members' fees. Cooperative marketing helps to make the multi-material collection of recyclables more affordable. Three legal structures are employed; nonprofit organization, inter-municipal agreement, and resolution agreement. These vary in the formality of the contractual commitment, powers to let contracts, administrative flexibility, and availability to private businesses, as opposed to business-government mixes. Some have put-or-pay clauses to guarantee volume. A structure of this sort might be tailored for PVM recycling, especially if its infrastructure piggybacks onto that for the electronics industry.

\subsection{Recycling Hotline for Do-lt-Yourself}

Recycling infrastructure has grown rapidly for used automotive oil filters; 110 recyclers belong to the Filter Manufacturers' Council, many of whom are branches of used oil recycling companies.33 The Council established a Recycling Hotline

33. The following are the institutional infrastructures for these industries:

USED MOTOR AND LUBRICATION OIL. Less than $1 \%$ of the 1.35 billion gallons of used motor and lubrication oils generated annually is recycled. Recycling is done in privately owned re-refineries with capacities generally between 7.5 and $\mathbf{4 0}$ million gallons per year. The resulting motor oil, lubrication oil, and miscellaneous industrial chemicals are sold to small blenders and compounders, who retum it to industrial and automotive markets, Some motor oils made from recycled oils are sold by retailers.

Most re-refining companies run their own fleets ( 60 trucks for one typical company) that collect from industrial accounts, car dealers, service stations, quick-lube shops, and scrap auto dealers. Generators usually pay to have the discarded oil removed by the gallon ( 20 to 25 cents in 1992) or per pickup (about $\$ 50$ for up to 250 gallons), with distance and freight rates factored in. Some customers bring in their own oil to the re-refinery, but this is discouraged.

Some re-refiners obtain used oil from oil distributors, who receive 20 cents per gallon, or contract out to independent haulers. A few companies sell their recycled lubrication oil to customers with a promise to buy it back for another round of recycling.

The main problems in this recycling system are controlling the supply and quality of the used oil, regulatory compliance, facility permitting, and shaky profitability. The major oil companies only reluctantly support re-refining.

USED MOTOR-OIL FILTERS The oil-filter recycling infrastructure is similar. EPA deems the filters to be non-hazardous if they are drained of free-flowing used oil. At a cost of between 15 and 80 cents per filter, perhaps $5 \%$ of the 400 million filters generated annually were recycled in 1993; this rate appears to have doubled in 1994 [Warren and Cohoon 1995]. A 55-gallon drum holds 250 uncrushed filters. Steel 
(something the PVM industry should consider), and experimented with special programs to induce weekend mechanics and other do-it-yourselfers to make a special trip to bring the filters (and used motor and lubrication oil) to recycling locations. Retailers who accept filters for recycling find that do-it-yourselfers make an extra $\$ 13$ of purchases per trip. This generation of extra sales associated with campaigns to induce special trips to return old PVMs might make retailers more interested in participating in take-back efforts.

\subsection{Designing Stackable, Standardized PVMs for Cheaper Shipping}

The costs of transporting and handling PVM modules can be reduced by designing the PVMs so that they can be stacked in trucks, are ergonomically suitable, have standardized dimensions, and so that any PVM shipping containers are themselves reusable, stackable, standardized; preferably, when empty they should be collapsible, and perhaps forklift-accessible to reduce backhauling costs, and perhaps to enable the containers to be used for other items between PVM shipments [Saphire, 1994]. PVM manufacturers should consider these design issues early on, in cooperation with reverse logistics carriers.

\subsection{Public Relations Initiatives to Focus Interest in PVM Recycling}

The PVM industry could proclaim an Environmentally Conscious Product Initiative, and cooperate with the National Center for Manufacturing Sciences, the EPA Energy Star Program, and numerous other groups and programs working on pollution prevention, design for recyclability, and resource conservation.34 Logos could be developed for Certified Recyclers, and Recyclable PVMs.

\subsection{Modifying MRFs to Accommodate PVMs}

The PVM industry might finance additions to existing MRFs to accommodate the dismantlement, sorting, and simple shredding or crushing of PVMs. ${ }^{35}$ Automated inspection systems being designed for electronics disassembly may be applicable to PVMs.

and iron are recovered in electric arc mini-mills, along with the used oil. One mill pays $\$ 40 /$ ton to acquire densified filters, and $\$ 80 /$ ton for shredded ones.

34. Industry plans to design products for recyclability should aim for fewer kinds of materials, materials that are more compatible, easier for disassemble, with fewer, easily removable coatings, and identifications of parts.

35. Capital and operating!costs could be pro-rated by the material or product, along the lines of Tellus (1991). 


\subsection{Follow-up Research Studies}

Two economic studies are needed: One on the break-even tipping fee for a PVM recycling facility and another on collection costs. The first study can follow the methodology of a 1994 study on the economics of refrigerator recycling [Zolotor and Fisher, 1994], which evaluated cost as a function of daily volume for manual and automated operations. The second study would project collection costs for various schedules, equipment, and logistics, following the method used in Hegberg et al. (1992). The results of both studies should be integrated into the life-cycle study recommended below.

We recommend that detailed economic and logistical analyses are prepared for the three institutional infrastructure paradigms identified in this report, for various scenarios of PVM penetration, and that the PVM industry begin discussions with several companies designated in this report to expand promising arrangements for institutional infrastructures. This approach should lead to the preparation of definitive institutional infrastructure plan(s) for one or more preferred recycling process(es).

Work on PVM recycling has reached the point where a full life-cycle study is necessary and feasible. The study would examine the total system waste, energy, resource, and dollar savings associated with making, using, and recycling photovoltaic modules, and examine tradeoffs associated with individual options for designing the PVM institutional and technological architecture. 


\section{REFERENCES CITED}

Much of the information for this report was obtained from interviews with individuals in companies, trade associations, and government agencies, and from company product and technical literature. Approximately 40 trade organizations and 25 companies were contacted.

Advance Recovery, Inc., Literature on computer recycling service. Bellevue, NJ 1994.

Allenby, B., and Richards, D., The Greening of Industrial Ecosystems, National Academy Press, Washington, DC 1994.

American Plastics Council, Repair and Reuse of Automotive Plastic Parts, 1994.

American Plastics Council, Disposal Practices for Post-Use Automotive Plastics, 1994.

American Plastics Council, Sorting and Processing Automotive Plastics - Emerging Technologies, 1994.

American Plastics Council, Economics of Recovery and Recycling, 1994.

American Plastics Council, Composition, Properties, and Economic Study of Recycled Refrigerators, 1994.

American Plastics Council, Stretch Wrap Recycling, 1994.

Anderson, P., and Rattray, T., "Recycling plastic containers: the arrival of vertical integration," Resource Recycling, September, 1994, pp. 77-82.

Apotheker, S., "Steel can scrap recycling demands," Resource Recycling, February 1995, pp. 16-24.

Apotheker, S., "Two, four, six, eight, time to beneficiate," Resource Recycling, October, 1994, pp. 14ff.

ATT Bell Labs, Flow charts describing waste management system for computers, circuit boards, and other waste materials. Middletown, NJ 1994.

Battery Council International, "Proposed Model Battery Recycling Legislation," Chicago, IL, 1994.

Battery Council International, "Summary of Lead-Acid Battery Laws as of July 1, 1994," Chicago, IL, 1994. 
Baumann, W., and Muth, A., Abfallverhalten neuartiger Batterien: Mengen, Inhaltsstoffe. Verwertungs- und Behandlungsmethoden von Batterien, Deutsche Bundesumweltamt, Berlin, 1993.

Biddle, M., and Fisher, M., "An overview of the recycling of plastics from durable goods," presented at Society of Plastics Engineers' International Recycling Conference, Schaumburg, IL, November 3 and 4, 1994.

Boone, A., "Couches and mattresses: the next recoverables?" Resource Recycling, October, 1994, pp. 45-48.

Borsecnik, J., "Computer recycling ahead," Scrap Processing and Recycling, January 1995, pp. 53-62.

Breslow, M., "Reducing pollution and disposal costs by taxing materials," Resource Recycling, June 1993, pp. 82-86.

Bright, R. and Leigh, R., "Photovoltaics and electric utilities," Energy vol. 9, no. 2, pp. 125-147.

Burt, J., and Dillon, P., "What the US can learn from Germany's packaging take-back system," Resource Recycling," September, 1994, pp. 87-89.

Busche, R., ed., Opportunities for Innovation: Biotechnology, Technomic Publishers, Lancaster, PA, December, 1994.

Cohen, S., "Recycling nickel-cadmium batteries," Resource Recycling, August, 1993, pp. 47-54.

Crawford, C., "Paint and aerosol can recycling," p. 31 in C. Crawford, "What's new in steel can recycling," Resource Recycling, February 1993, pp. 27-34.

DePhillips, M., and Moskowitz, P., "A Review of Incentives, Strategies, and Model Technologies for Recycling Photovoltaic Modules." Brookhaven National Laboratory, Upton, New York, unpublished.

DePhillips, M., Fthenakis, V., and Moskowitz, P., "Waste Reduction Options for Manufacturers of Copper Indium Diselenide Photovoltaic Cells." Brookhaven National Laboratory, Upton, New York, unpublished.

Dong, M., "A case study in financing a start-up: FulCircle Ballast Recyclers," New York State Energy Research and Development Authority, Proceedings of 1992 North American Conference on Industrial Recycling and Waste Exchange, pp. VII-8 to VII-20. 
Eberspacher, C. (Unisun Corp.), Letter to S. Johnson, Golden Photon Co., submitted to Environmental, Health, and Safety Working Group begun at WCPEC, Hawaii, December, 1994. December 21, 1994.

Eberspacher, C. and Gay, C., "Strategies for Gaining Acceptance of CdTe-Based Photovoltaics: CdTe E,H,\&S Commercialization Issues." Report prepared for Brookhaven National Laboratory by Unisun, Inc., Golden, Colorado. May 1994.

Ehrig, R., "International Corner," Plastics Recycling Division Newsletter, Society of Plastics Engineers, November 1, 1994, unpublished.

Fekert, D., "The aluminum industry: market, pollution control, and scrap," Pollution Prevention Seminar, SUNY Stony Brook, December, 1994, unpublished.

Franklin Associates, Ltd., The Role of Recycling in Integrated Solid Waste Management to the Year 2000. Two volumes. Keep America Beautiful, Inc., Stamford, CT, September 1994.

Franklin, P., "Sweden's aluminum can return system," Resource Recycling, March, 1993 , pp. $66 \mathrm{ff}$.

Gouchoe, S., James, M., Lynch, K., et al., Evaluation of the Effectiveness of Industry Pollution Prevention Planning Requirements and Guidance for Integrating Pollution Prevention Plans, Tufts University Department of Civil and Environmental Engineering, November, 1994.

Hagan, R., Key Materials for Innovation and Productivity in Major Appliances, American Plastics Council, Washington, DC, February 1994.

Hart, V., "Mercury reclamation and recycling from industrial materials," in Government Institutes, Proceedings of 1992 North American Conference on Industrial Recycling and Waste Exchange, 1992, pp. V-1 to V-8.

Hegberg, B., Brenniman, G., and Hallenbeck, W., Mixed Plastics Recycling Technology, Noyes Data Corporation, Park Ridge, NJ, 1992.

Huang, P., ed., Hazardous and Industrial Wastes, Proceedings from the 26th MidAtlantic Industrial Waste Conference, Univ. of Delaware, August 7-10, 1994. Technomic Publishing Co., Lancaster, PA 1994:

IGT, "Remediation of metal-contaminated solids and liquids," Technology Spotlight, Institute of Gas Technology, Des Plaines, IL, December, 1994.

Institute of Scrap Recycling Industries, "Lead-Acid Battery Recycling and Marketing Credits for Secondary Lead Recycling," ISRI, Washington, DC, 1994. 
Kirby, J., and Pitts, D., "Computer Recycling: Progress and Challenges," IBM Engineering Center for Environmentally Conscious Products, Research Triangle Park, NC, 1994.

Kulik, A., "France speeds ahead with vehicle recycling," World Wastes, January, 1995, p. 6.

Kuster, T., "Foreign trade in aluminum cans: down but (probably) not out," Resource Recycling, March, 1993, pp. 34ff.

Leaversuch, R., "Legislation is having a mixed impact on worldwide recycling," Modern Plastics, December, 1994, pp. 16-18.

Lockwood, C., "Born-again computers," New York Times, February 1, 1995.

McCutcheon, A. "Aluminum can recycling overcomes rocky start." Resource Recycling, October, 1992, pp. 40-43f.

McDonald, T., Digital Equipment Corporation Waste Management Initiative, Digital Equipment Corporation, Maynard, MA, 1993 (26 pages).

Meyerson, A., "Solar power, for earthly prices," New York Times, November 15, 1994, pp. D1-D2.

Miranda, M., "Managing solid waste: the unit-pricing approach," Resource Recycling, November, 1993, pp. 37-40.

Moskowitz, P., and Zweibel, K., eds., Recycling of Cadmium and Selenium from Photovoltaic Modules and Manufacture Waste: a Workshop Report. Recycling of Cadmium and Selenium from Photovoltaic Modules and Manufacturing Wastes, Golden, Colorado, March 11-12, 1992. Report No. BNL 47787. Brookhaven National Laboratory, Upton, NY.

National Recycling Coalition, 1994 Market Development Directory, National Recycling Coalition, Inc., Washington, DC, 1994.

New Jersey Department of Environmental Protection and Energy, correspondence to and from Alexander Batteries, Duracell, Inc., Panasonic, National Electric Manufacturers Association, Rayovac Corporation, and The Lindemann Concern, on mercuric-oxide hearing-aid batteries, hospital and nursing home users, other special battery types, $1992-1993$.

New York Power Authority, "New York Power Authority Photovoltaic Program," New York, NY 1994. 
New York State Department of Environmental Conservation, New York State Department of Economic Development, and New York State Battery Task Force, "Report on Dry Cell Batteries in New York State," December, 1992.

Northeast Industrial Waste Exchange, Listings Catalog, Issue No. 52, NEIWE, Syracuse, NY, Autumn, 1994.

Orton, J., "Taking back electrical goods," WARMER Bulletin, February, 1995, pp. 1214.

Papke, C., "Trends in glass container recycling," Resource Recycling, June, 1993, pp. 22ff.

Parry, J., "Plants absorb heavy metals," Pollution Engineering. February 1995, pp. 4041.

Perkins, R., "Collection economics for recycling: a new methodology," Council for Solid Waste Solutions, 1992.

Portable Rechargeable Battery Association, Joint Battery Management Plan for the State of New Jersey, Revised version, January 5, 1993. PRBA, Atlanta.

Reaven, S. 1994(a) "Recycling and Waste Minimization Prospects for Photovoltaic Modules: a Preliminary Assessment," Working Paper prepared for Brookhaven National Laboratory, August, 1994.

Reaven, S. 1994(b). Prospects for Pyrolysis Technologies in Managing Municipal, Industrial, and Department of Energy Cleanup Wastes. Report No. BNL-52452, Brookhaven National Laboratory, December, 1994.

Reaven, S., "Waste Minimization Compliance in Business and Industry." Waste Management Research Report, vol. 6, no. 1., pp. 9-12, 1994.

Reaven, S. "Energy Impacts of the Manufacture and Use of Lumber from Recycled Plastics." In Breslin, V., Reaven, SD., Schubel, J., Swanson, R., Zweig, M., and Bortman, M., Secondary Materials: Engineering Properties, Environmental Consequences, and Social and Economic Impacts. Final Report, No. 1536-ERERPOP-91. New York State Energy Research and Development Authority, Albany, NY., 1993.

Reaven, S., "Energy Impacts of Manufacture and Use of Construction Blocks Made from Incinerator Ash." In Breslin, V., Reaven, SD., Schubel, J., Swanson, R., Zweig, M., and Bortman, M., Secondary Materials: Engineering Properties, Environmental Consequences, and Social and Economic Impacts. Final Report, No. 1536-ERER- 
POP-91. New York State Energy Research and Development Authority, Albany, NY, 1993.

Reaven, S., "Life-Cycle Energy, Resource, and Environmental Impacts." In Swanson, R., Breslin, V., Reaven, S., Ross, S., Young, R., and Becker, R., An Assessment of Impacts Associated with Implementation of the Suffolk County Plastics Law, Local Law 10-1988. Special Report No. 106. Waste Management Institute, State University of New York at Stony Brook, 1993.

Reaven, S., "Waste Minimization Compliance in Electronics Manufacturing." Presentation to Workshop on CFC Replacement in Printed Circuit Manufacturing, March 17, 1993, State University of New York at Stony Brook, 1993.

Reaven, S., "Measuring Waste Minimization in the Oil Industry." Manuscript report prepared for American Petroleum Institute, 1992.

Rechargeable Battery Recycling Corporation, "Recycling America's Rechargeable Batteries: The Program," RBRC, Upper Saddle River, NJ, 1994.

Rechargeable Battery Recycling Corporation, Information and License Agreement Forms Kit on RBRC National Battery Collection Program (contains various documents), RBRC, Upper Saddle River, NJ, February, 1995.

Resource Recycling, Inc., The Recyclers' Directory 1993 edition. Portland, OR.

Siuru, B., "Car recycling in Germany," Resource Recycling, February, 1991, pp. 76-79.

Sandwich, D., "Development of CdTe module manufacturing," in Proceedings of First WCPEC, held in Hawaii, Dec. 8, 1994.

Saphire, D., Delivering the Goods: Benefits of Reusable Shipping Containers, INFORM, Inc., New York, NY, 1994.

Sasala, R., Zhou, T., and Kocher, W., "Environmentally responsible production, use, and disposition of Cd-bearing PV modules," in Proceedings of First WCPEC, held in Hawaii, Dec. 8, 1994.

Senate of New Jersey, Dry Cell Battery Management Act (S-3157), Trenton, NJ, Adopted February 4, 1991.

Sikora, M., "Market development: key to tire recycling," Resource Recovery, April, 1994, pp. 30ff.

Smith, Bucklin and Assoçiates, 1992 National Recycling Rate Study, Chicago, IL, March, 1994. 
Snyder, M., "Granulators are riding the recycling wave," Modern Plastics, October, 1994, pp. 69-71.

Solsky, S., and McCarthy, R., "Financing Environmental Projects," Pollution Engineering, March, 1995, pp. 40-43.

Tellus Institute, Disposal Cost Fee Study: Final Report, California Integrated Waste Management Board, Sacramento, February 15, 1991.

Texas Recycling and Refining, Inc., "Services Offered" and other company literature. Houston, TX, 1994 and 1995.

Torrance, I., et. al., "The 1990 Clean Air Act Amendments: Overview, Utility Industry responses, and Strategic Implications." Annual Review of Energy and Environment, vol. 17, pp. 211-233, 1992.

U. S. Congress Office of Technology Assessment, Green Products by Design: Choices for a Cleaner Environment. Report No. OTA-E-541. Washington, D.C. October 1992.

U. S. Department of Energy, Model Pollution Prevention Opportunity Assessment Guidance. U.S. Department of Energy, Washington, D.C. Revised, December 1993.

U. S. Environmental Protection Agency, Innovative Treatment Technologies: Annual Status Report (Sixth Edition), EPA 542-R-94-005, No. 6, September, 1994.

U. S. Environmental Protection Agency, Waste Analysis: EPA Guidance Manual for Facilities that Generate, Treat, Store, and Dispose of Hazardous Wastes, Government Institutes, 1994.

U. S. Environmental Protection Agency, Final Rule, 40 C.F.R. Part 273 [proposed final version submitted to Office of Management and Budget of "universal waste" modifications of hazardous waste recycling regulatory program], Washington, DC, March, 1995

van der Linde, C., "Competitive Implications of Environmental Regulation in the Dry Cell Battery Industry," in Management Institute for Environment and Business and US Environmental Protection Agency, Competitive Implications of Environmental Regulations: a Study of Six Industries, MIEB, Washington, DC, 1994.

Warren, T., and Cohoon, S., "Recycling used oil filters," Resource Recycling, February, 1995, pp. 44-53.

Watson, T., "Major retailers sold on recycling," Resource Recycling, March, 1993, pp. $56 \mathrm{ff}$. 
Weinberg, David G., Memorandum on Final Part 273 Rule, to PRBA Operating

Committee, PRBA Legislative Committee, and PRBA Recycling Committee, Weinberg, Bereson, and Neuman, Washington, DC, March 7, 1995.

Wigotsky, V., "Plastics vs. Metals," Plastics Engineering, December 1993, pp. 20-24.

Wigotsky, V., "Recycling making headway," Plastics Engineering, December, 1994, pp. 20-24.

Watts, M., "Moving recyclables: the art of the backhaul," Resource Recycling, October, 1994, pp. 26-31.

Zolotor, A., and Fisher, M., Composition, Properties, and Economic Study of Recycled Refrigerators, American Plastic Council, Washington, DC, April, 1994.

(Unsigned), "Pantex recycles tires, fluorescent lamps," Pollution Prevention Advisor, vol. 4, no. 6, US Department of Energy, October, 1994, p. 6.

(Unsigned), "Das Konzept der Batterieindustrie: Batterien fur den Umweltschutz," ZVEI, 1993.

(Unsigned), "UK Industry proposes a recycling scheme," Modern Plastics, January, 1994, p. 15.

(Unsigned), "Capturing sound, light, and strength with new materials," Science, vol. 266, December 16, 1994, p. 1807.

(Unsigned), "Metal-filled resins sparked by EMI-shielding needs," Modern Plastics, August, 1994, p. 20-21.

(Unsigned), "Electronic scrap recovery." Unsigned. Warmer Bulletin, May 1994, p. 14. 


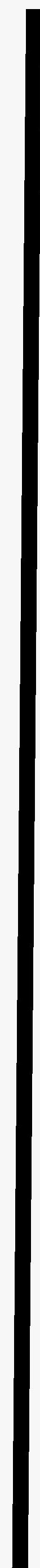

